\title{
Strategy for Community Adaptation in Facing Flood Natural Disasters in Pesisir Selatan District, West Sumatra
}

\author{
*Triyatno ${ }^{1}$, Ikhwan $^{2}$, and Febriandi ${ }^{1}$ \\ ${ }^{1)}$ Postgraduate Doctoral Program in Environmental Sciences, Universitas Negeri Padang, Indonesia \\ email: triyatno@fis.unp.ac.id
}

*Corresponding Author, Received: October31, 2018, Revised: November 25, 2018, Accepted: December5, 2018

This is an open acces article distributed under the Creative Commons 4.0 Attribution License, wich permits unrestricted use, Distribution, and reproduction in any medium provided the original work is properly cited @2017 by author and Universitas Negeri Padang

\begin{abstract}
Adaptation of the community to flood natural disasters is part of the flood mitigation natural disaster that often occurs in the rainy season. The aims of this research are to analyze landform units and land characteristics that have flood hazards and community adaptation strategies in dealing with flood natural disasters. The method used in this research is the survey method, which is to collect data on land characteristics as characteristics or characteristics of flooded areas and interviews with local communities about adaptation strategies undertaken to deal with flood natural disasters. The results showed that the landform units formed due to the flood process in the study area were in the form of floodplains, back swamps, alluvial terraces, depression inter beach ridge, and alluvial plain complexes. The unit characteristics of landforms generally have flat morphometry with slopes ranging from $0-2 \%$, the genesis of these landform units due to fluvial and marine processes. The constituent material in this area is mud to coarse sand. The rock conditions in this area are rocks originating from volcanoes and undergoing a process of destruction due to processes from the river so that the rocks in this area are gravel, rough sand, fine sand. Soil conditions in each unit of landform also vary from the formation of soil to on newly developed land. Vegetation that grows in each unit landform of this is in the form of natural vegetation and lovely water vegetation or vegetation which requires a lot of water for its growth and development. The community strategy in dealing with flood natural disasters is in the form of staging houses, knowing the time of occurrence of tides, and opening the river estuary if the river estuary is covered by sediment.
\end{abstract}

Keywords: Landforms, Land Characteristics, Adaptation Strategies.

\section{Introduction}

Indonesia is a country that has a very complex potential for disasters, this is due to Indonesia's geographical location in the equator. Indonesia is also located at the confluence of three large plates of the world, namely the Indo_australian plate, the Eurasian plate, and the Pacific plate. As a result of Indonesia's geographical location, Indonesia has the potential for natural disasters in the form of floods, flash floods, droughts, volcanic eruptions, landslides, earthquakes, tsunamis, forest and land fires (Hermon, 2012).

Natural disasters that often occur during the rainy season are floods, flash floods, and landslides ( $\mathrm{Su}$ Rito et al., 2011; Anggara et al., 2013; Muh Aris et al., 2014; Oktorie, 2017). The intensity of natural disaster events in the Indonesian region tends to increase from year to year, this causes losses due to natural disasters 
tend to increase along with the intensity of the occurrence of natural disasters. Regions that have the potential for natural disasters generally have their own characteristics, which are formed as a result of past natural disasters (K.J. Gregory et al., 2008; Hermon, 2015). To find out the potential of natural disasters that occur in an area can be seen from the constituent material of the land that is characteristic of the land due to natural disaster activities that occurred in the past. Most of the people who live in areas that have the potential for natural disasters have adaptation patterns to adapt to the natural disasters that will occur in the future (Nick et al., 2005; ISDR, 2009; Hermon, 2014; Sampei et al., 2016). This community adaptation is generally inherited by their ancestors, who had already lived in the area (Jeannette et al., 2006; Hongjian et al., 2016; Hermon, 2016; Hermon, 2017). The development of science and technology in recent years has also led to changes in the adaptation of people living in areas that have the potential for floods. One of the areas in West Sumatra that often occurs in natural disasters is Pesisir Selatan District, which is located in the southern part of the city of Padang (Hermon, 2010). The occurrence of this natural catastrophic flood often occurs in plain areas near the coast, causing loss of property and also the human soul, as happened in the Kambang area. The flooding that occurred in this area caused losses in the form of the destruction of several houses, the breakdown of the Painan-Bengkulu highway and human casualties. To reduce losses due to natural floods, mitigation measures need to be taken in the form of knowing the landform units and characteristics of the land that have the potential for natural floods, as well as community adaptation strategies in the face of floods.

\section{Method}

The method used in this study is the survey method, namely by taking measurements in the field and interviews with the community. Measurements in the field were carried out to determine the characteristics of the land that has the potential for floods and interview techniques to determine the community's adaptation strategies in the face of floods that often occur in the rainy season.

\section{Stages of Research}

The research is carried out through several stages, namely the pre-field stage, the field stage, and the post-field stage, while the details of the activities are as follows;

Pre-field stage

The activities carried out at this stage are preparing literature related to the problem of good research from previous research reports and journals related to flood natural disasters. Prepare satellite imagery and maps needed to carry out data collection in the field and determine sample points for field data retrieval, especially those related to the characteristics of land which has the potential for flood natural disasters.

Stage Field

At this stage, the sample map is matched with the actual conditions in the field, after which sampling characteristics of the land that has the potential for a natural catastrophic flood are carried out. The characteristics of land collected in the field are data collection, geology, geomorphology, soil, hydrological conditions, and land use. To find out the adaptation star great to flood natural disasters, interviews were conducted with communities living in areas that have the potential for floods.

\section{Post-Field Stages}

The post-field stage is an activity carried out after completion of collecting data in the field. Activities carried out at this stage are classifying data, tabulating data, analyzing data, and interpreting data to draw conclusions. Make a map of results and research reports.

\section{Data analysis}

Analysis of the data used to answer this research question is as follows; 
a. To determine the landform units that have the potential for natural disasters floods are to use a geomorphological approach and interpretation of satellite images to determine the boundaries of landform units. The landform units that have the potential for flooding can be seen from the constituent material, vegetation type, and regional morphometry (K.J. Gregory et al., 2008; Ellen et al., 2011),

b. To find out the community's strategy in dealing with floods natural disasters are conducted by interviewing local communities, especially those who live in areas that often experience flooding (Su Rito et al., 2011; Muh Aris et al., 2014).

\section{Results and Discussion}

Land characteristics are a characteristic of land that distinguishes one land from another. The characteristics of the land in the flood area can be seen from the constituent material of the land which is in the form of material carried by the river and deposited on the left side of the river (Jeannetteet al., 2006; Barry et al., 2011; Kai Kai et al., 2018; Putra et al., 2017). Differences in land characteristics can be seen from landform units found in the area around the river flow. The characteristics of the land as a marker for flood areas can be seen in the following table:

Table 1. Characteristics of Land in Flood Areas

\begin{tabular}{|c|c|c|c|c|c|c|c|}
\hline \multicolumn{8}{|c|}{ Land Characteristics } \\
\hline NO & Landform & $\begin{array}{c}\text { Relief- } \\
\text { morphology }\end{array}$ & Processes & Rock Type & Soil & $\begin{array}{l}\text { Hydrologic } \\
\text { Situation }\end{array}$ & $\begin{array}{l}\text { Vegetaion- } \\
\text { Land Use }\end{array}$ \\
\hline 1 & floodplain & $\begin{array}{l}\text { Almost flat land, } \\
\text { disekitar aliran } \\
\text { sungai }\end{array}$ & $\begin{array}{l}\text { Results of } \\
\text { river } \\
\text { deposits }\end{array}$ & $\begin{array}{l}\text { Mud, sand or pebbles in } \\
\text { tropical countries, } \\
\text { beach rock may be } \\
\text { formed by } \\
\text { sedimentation of river }\end{array}$ & $\begin{array}{l}\text { No soil } \\
\text { development }\end{array}$ & $\begin{array}{l}\text { Shallow } \\
\text { groundwater }\end{array}$ & $\begin{array}{l}\text { Typical } \\
\text { absence of } \\
\text { vegetation: no } \\
\text { agriculture, }\end{array}$ \\
\hline 3 & $\begin{array}{l}\text { Alluvial } \\
\text { terrace }\end{array}$ & $\begin{array}{l}\text { Smooth surface, } \\
\text { morfometri } \\
\text { berupa dataran }\end{array}$ & $\begin{array}{l}\text { Results of } \\
\text { river } \\
\text { deposits }\end{array}$ & All kind of rock & $\begin{array}{l}\text { Tanah mulai } \\
\text { berkembang, } \\
\text { solum tanah } \\
\text { dangkal }\end{array}$ & $\begin{array}{l}\text { Groundwater is } \\
\text { good }\end{array}$ & $\begin{array}{l}\text { Cover of } \\
\text { natural } \\
\text { vegetation, the } \\
\text { farther from } \\
\text { the river } \\
\text { shows the old } \\
\text { alluvial terrace } \\
\text { with varied } \\
\text { vegetation }\end{array}$ \\
\hline $\begin{array}{l}4 \\
.\end{array}$ & $\begin{array}{l}\text { Depressio } \\
\mathrm{n} \text { inter } \\
\text { beach } \\
\text { ridge }\end{array}$ & $\begin{array}{l}\text { Elongated ridges, } \\
\text { more or less } \\
\text { parallel to one } \\
\text { another, varying } \\
\text { to height. The } \\
\text { surface may be } \\
\text { smooth, or } \\
\text { irrigular. } \\
\text { Elongated, } \\
\text { almost flat } \\
\text { bottomed } \\
\text { depressions may } \\
\text { separate the ridge }\end{array}$ & $\begin{array}{l}\text { Results of } \\
\text { marine } \\
\text { activity }\end{array}$ & $\begin{array}{l}\text { Basically fine sand, but } \\
\text { gravel and shells may } \\
\text { be included or } \\
\text { dominante. The } \\
\text { interridge depressions } \\
\text { may contain finer } \\
\text { sediments. }\end{array}$ & $\begin{array}{l}\text { Young beach } \\
\text { ridges may have } \\
\text { a vary limited } \\
\text { soil } \\
\text { development.ol } \\
\text { der ridges, } \\
\text { especially in the } \\
\text { humid tropics, } \\
\text { may have deep } \\
\text { soils. The } \\
\text { interridge } \\
\text { depressions may } \\
\text { display soil } \\
\text { development }\end{array}$ & $\begin{array}{l}\text { In principle, in } \\
\text { drained ground } \\
\text { saltwater may be } \\
\text { available, } \\
\text { particularly in } \\
\text { intensive beach } \\
\text { ridge complexes. } \\
\text { The interridge } \\
\text { depressions are } \\
\text { frequently wet }\end{array}$ & $\begin{array}{l}\text { Cover of } \\
\text { natural } \\
\text { vegetation } \\
\text { typically } \\
\text { ranges from } \\
\text { open to dense. } \\
\text { The interridge } \\
\text { depressions } \\
\text { are densely } \\
\text { vegetated or } \\
\text { nypa and } \\
\text { mangrove }\end{array}$ \\
\hline
\end{tabular}

Source: Data analysis, 2017 
Based on the table above the characteristics of the land in the flood area can be seen from the characteristics of the area. The characteristics of the land due to the flooding process can be seen from the units of land formed around the river in the form of floodplains, rear swamps, alluvial terraces, depression between the sandbanks, and the alluvial plain complex. The unit of the floodplain landform has a morphometry in the form of a plain located on the left-right side of the river, this landform unit is formed due to sediment from material carried by flooding, the land in the floodplain landforms has not developed and is still fresh, rough and gravel sand that is still fresh. Groundwater conditions are generally good and vegetation that grows in the form of plants that like water or plants that need a lot of water. For more details, can be seen in Figure 1 as follows.

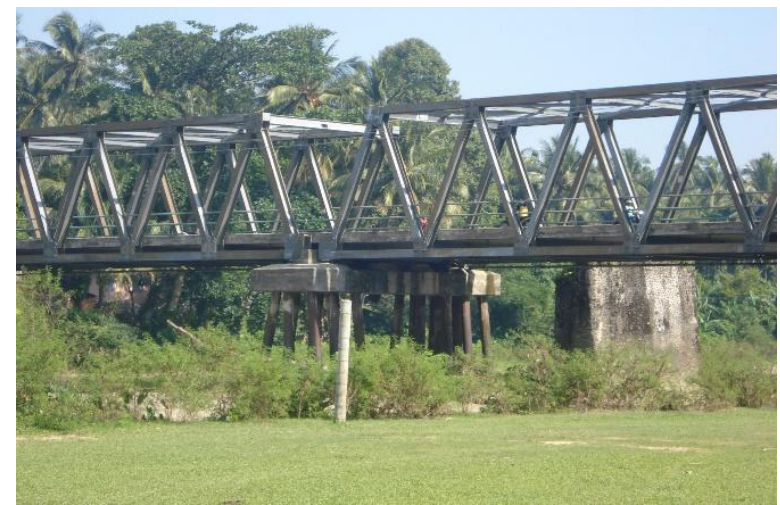

Figure 1. Flood Plain in Batang Kapas District

Source: 2017 Research Documentation

Based on the figure on the floodplain in the study area still has natural vegetation in the form of grass and white plants, this shows that this flood plain still has a direct influence from flood natural disasters. The unit landform of the back swamp has morphometry in the form of a basin that is often flooded by water. The constituent material in the rear swamp landform unit is a material that has a fine size such as sand, fine sand, and mud. The vegetation that grows in the rear swamp is a plant that requires a lot of water, and is not good for use as agricultural land. The potential for groundwater is relatively large but usually has a $\mathrm{pH}$ of acidic water because it is always flooded by water. The unit of the form of alluvial terraces is formed due to the process of river erosion that is vertical in nature, this is because the river bedrock is not hard so it is easily crushed by river water. The alluvial terrace morphometry is in the form of terraced terrain, the farther away from the river flow shows the earliest terrace formed and the closer to the river flow shows the newly formed terrace. Old alluvial terraces generally have developed from the ground but still have a shallow soil solum that is $20-25 \mathrm{~cm}$, while on the alluvial terrace that is still young has not shown the development of the soil, which is a fine sand fine material to coarse sand and gravel and has little natural vegetation. The potential of groundwater is generally good because the alluvial terrace landform unit has a constituent material in the form of sand and gravel. The unit of the shape of the depression between the sandstones is a form of land formed by a process originating from the sea. Unit morphometry in the form of depressed land between pistons in the form of a basin so that it has the potential for flooding. The constituent material in this landform unit is in the form of mud until fine sand is formed due to material carried by rising river water or due to the sea water that is installed. The hydrological potential of depression among the pebbles can be brackish water, whereas in the depression between old physical shelters the potential for water is in the form of fresh water but usually has a low or acidic water $\mathrm{pH}$. The vegetation that usually grows in units of depressive land forms between the sandbanks and mangroves. In units of depressed land forms between old physical shelters can already be used as rice fields because they have no influence from sea water. The unit of landform of the complex alluvial plain is a unit of land formed by two processes, namely due to river flow and tidal sea water (Qinget al., 2016; Putra et al., 2013; Tomet al., 2017). As a result of the two masses of water that meet at the mouth of the river resulting in overflow around the river mouth. The constituent material in the landform unit of the alluvial plain complex is in the form of mud and fine sand, this is due to the fact that two water masses lose their driving energy so that the water mass seems to stop flowing and results in overflow. Generally the landform units of the alluvial plain complex have brackish groundwater potential because of the influence of the tidal sea water. The vegetation that grows in this landform unit is 
natural vegetation and is not good for farming. For more details, please see the following Flood Hazard Map in South Coastal District; Based on the picture above, the flood hazard in the study area is spread almost throughout the study area, this shows that the plains in the South Coastal District are formed due to the influence of the sedimentation process both from the land and from the sea. The widest distribution of flooding is in Lunang Silaut District. Most of this area is used for oil palm plantations. For more details, see the following Tables and Figures:

Table 2. Flood Spatial Hazard Distribution in Pesisir Selatan District

\begin{tabular}{lrrr}
\hline \multicolumn{1}{c}{ Subdistrict } & $\begin{array}{c}\text { Medium hazard } \\
\text { Area } \\
\text { (ha) }\end{array}$ & $\begin{array}{c}\text { High Hazard Area } \\
\text { (ha) }\end{array}$ & Total area Hazard Banjir (ha) \\
\hline Basa Ampek Balai Tapan & 5.58 & 22196.97 & 22202.55 \\
Batang Kapas & 204.48 & 2334.15 & 2538.63 \\
Bayang & 282.78 & 2137.86 & 2424.60 \\
IV Nagari Bayang Utara & 43.38 & 60.93 & 104.31 \\
IV Jurai & 692.28 & 1141.47 & 1835.28 \\
Koto XI Tarusan & 1898.19 & 2244.06 & 6139.53 \\
Lengayang & 1142.1 & 7231.95 & 8374.05 \\
Linggo Sari Baganti & 1427.4 & 7989.03 & 9416.43 \\
Lunang Silaut & 1234.89 & 64314.63 & 65578.32 \\
Pancung Soal & 1055.52 & 42056.64 & 43112.16 \\
Ranah Pesisir & 888.12 & 5793.75 & 6681.87 \\
Sutera & 874.71 & 6887.25 & 7761.96 \\
\multicolumn{1}{c}{ Total Large } & 9749.43 & 164388.69 \\
\hline
\end{tabular}

Source: Data analysis, 2017.

Based on the table above the distribution of hazardous floods is found in Lunang Silaut Subdistrict, which is 64314.63 ha, most of this area is behind swamps which have now been used for oil palm plantations. The smallest flood hazard is found in Subdistrict IV Nagari Bayang Utara, this is because this area has a morphometry in the form of mountains with very steep slopes. Based on the network image above, it can be seen that Lunang Silaut Subdistrict which has the potential to spread experiencing floods, this is because most of this area is in the form of very large swamps which are close to the sea. The swamps in this area are made of channels to remove swamp water so that this area can be used as oil palm land both by the community and the company.Community adaptation to the dangers of flooding is an action taken by the community to adjust to the hazard of flooding that often occurs when the rainy season comes. The adaptation of the people in Pesisir Selatan District in the face of flood natural disasters is to make a house on stilts, for more details can be seen in Figures 2 and 3 as follows;

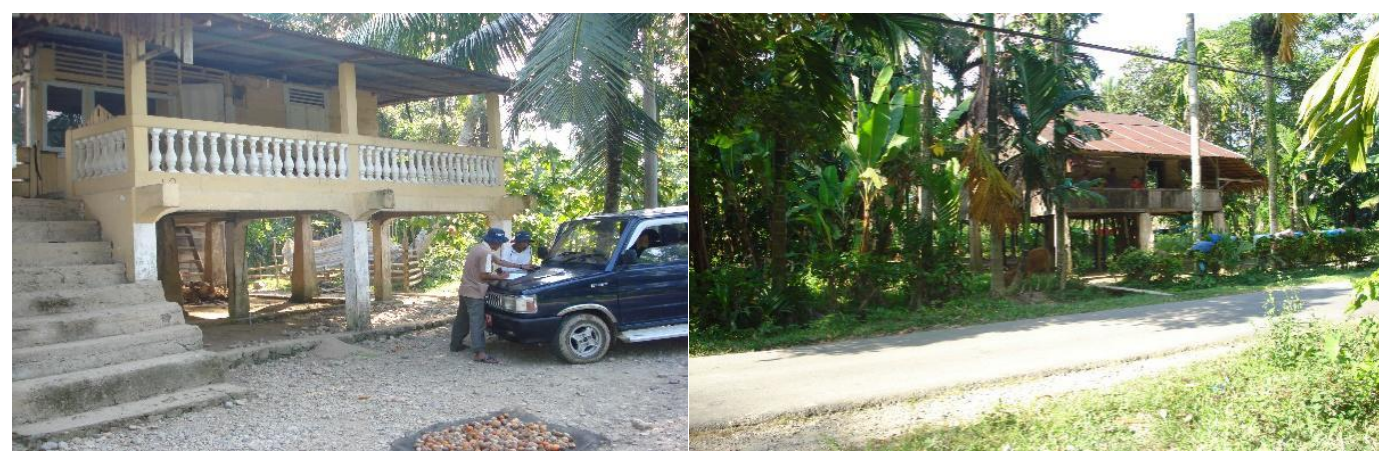

Figure 2. Permanent Stage Houses

Taratak Tampatih Area,

Batang Kapas Subdistrict,

Source: Research Documentation, 2017
Figure 3. Stage Houses Not permanent Taratak Tampatih Region Batang Kapas Subdistrict

Source: Research Documentation, 2017

Based on the picture above, the residents' houses were made a stage which aimed to avoid the entry of flood water into the house, this was made by self-help of the people living in areas that often experienced floods. The flood height in this area reaches $240 \mathrm{~cm}$ so that to anticipate the entry of water into the house, the stilt house is made with a height of more than $240 \mathrm{~cm}$. This stage house also functions not to 
disrupt the flow of water, so that the water reaches the river mouth faster and the duration of the flood is not too long. People choose the form of stilt houses in areas that have a flood hazard because the frequency of flooding in this area can reach $3 \mathrm{x}$ a year with the duration of flooding generally less than 24 hours, this indicates that this area has the potential to quickly receive floods (time to peak) when reaching the peak of the rapid and fast floods also floods to recede. Flood characteristics in this study area are very much determined by the pattern of river flows which are generally parallel ie perpendicular and the duration of rapid flooding is caused by very close river mouths. The community's adaptation strategy to deal with floods is to know the timing of sea tides, this is because flood events often coincide with the tide time. At the mouth of the river meets two masses of water, causing water from the mainland to be unable to enter the sea and sea water cannot enter the land through the river, this is what causes floods in the plains. Generally the flooding that occurs around the river mouth is in the form of overflow flooding because the river flow cannot accommodate the existing water. Knowledge of sea tide time is very much needed by the community because some of the people in the plains, especially those near the sea, have fishermen livelihoods, so knowledge of tide is very necessary to find fish in the sea when it is not in the rainy season. The community adaptation to overcome the flood disaster is by keeping the river estuary from being covered by sediments from land and sea. Usually people will see the river mouth when river water starts high, this is done to see the tidal conditions of the sea and also see the estuary door closed by sediment or not. Usually the community will work together to open the estuary from the sand deposits that cover the river mouth so that the river water flows faster into the sea and the faster the flood water will recede. This condition was carried out at the Batang Tarusan estuary by a young man who lives on Muaro Pulau Karam. Based on the above description of the community strategy in dealing with floods in the South Coastal District, conclusions can be drawn as follows;

1. Landform units that have the potential to be affected by floods are units of landforms of floodplains, rear swamps, alluvial terraces, depressions between sandstones, and alluvial terrain complexes.

2. The strategy of the people in facing floods is to make houses on stilts in areas that are frequently flooded, to know the time of tides, and to work together to open river mouths if sediment closure occurs.

\section{Conclusion} follows;

1. Increasing people's knowledge, especially in landform units that have the potential to be affected by floods,

2. Increasing people's knowledge especially about the time to reach the peak of the flood, (time to peak) so that the community knows how to mitigate floods,

3. Increasing community participation, especially in training on community adaptation strategies to deal with flood natural disasters.

\section{Reference}

Anggara, D.P and W. Handayani. 2013. Kajian Bentuk Adaptasi Terhadap Banjir dan Rob Berdasarkan Karakteristik Wilayah dan Aktivitas di Kelurahan Tanjung Mas, Jurnal Teknik PWK Volume 2. pp: 786-796

Barry E.F., E.W. Gregory., E.J. Hallisey., J.L. Heitgerd and B. Lewis. 2011. A Social Vulnerability Index for Disaster Management. Journal of Homeland Security and Emergency Management, Volume 8. Issue 1. pp: 1-22

Ellen, W., L.E. Polvi and D. Cadol. 2011. Wood Distribution Along Streams Draining Old-Growth Floodplain Forests in Congaree National Park, South Carolina, USA. Geomorphology 126 (2011). pp 108-120

Hermon, D. 2009. Dinamika Permukiman dan Arahan Kebijakan Pengembangan Permukiman pada Kawasan Rawan Longsor di Kota Padang. Disertasi. IPB Bogor. 
Hermon, D. 2010. Analisis Spasial Tingkat Bahaya Longsor Toposequent Marapi Bagian Barat Kab. Tanah Datar. Jurnal Geografi. Vol. 2.

Hermon, D. 2012. Mitigasi Bencana Hidrometeorlogi: Banjir, Longsor, Degradasi Lahan, Ekologi, Kekeringan, dan Puting Beliung. UNP Press. Padang.

Hermon, D. 2014. Arahan Mitigasi Bencana Longsor Kawasan Gunung Padang Kota Padang Sumatera Barat. Jurnal Geografi. Volume 9.

Hermon, D. 2015. Geografi Bencana Alam. Jakarta: PT RajaGrafindo Persada.

Hermon, Dedi. 2016. Mitigasi Perubahan Iklim. Rajawali Pers (Radjagrafindo).

Hermon, D. 2017. Climate Change Mitigation. Rajawali Pers (Radjagrafindo).

Hongjian, Z., X. Wang and J. Wang. 2016. AWay to Sustainability: Perspective of Resilience and Adaptation to Disaster. Sustainability 2016, 8, 737, pp 1-14

International Strategy for Disaster Reduction. 2009. Adaptation to Climate Change by Reducing Disaster Risks: Country Practices and Lessons, united Nation

Jeannette Sutton and Kathleen Tierney. 2006. Disaster Preparedness: Concepts, Guidance, and Research. Report prepared for the Fritz Institute Assessing Disaster Preparedness Conference Sebastopol, California, November 3 and 4, 2006. Natural Hazards Center Institute of Behavioral Science University of Colorado Boulder, $\mathrm{CO}$,

Gregory, K.J., G. Benito and P.W. Downs. 2008. Applying fluvial Geomorphology to River Channel Management:Background for Progress Towards a Palaeohydrology Protocol, Journal Geomorphology 98 (2008) 153-172

Kai, S., D. Molinari., M. Kunz and H. Kreibich. 2018. Natural Hazard Event Analysis for Risk Reduction and Adaptation. Journal Natural Hazard and Earth System Sciences, pp 963-968

Marfai, M.a., A. Cahyadi., A. A. Kasbullah., L. A. Hudaya and D.R. Tarigan. 2014. Dampak Bencana Banjir Pesisir dan Adaptasi Masyarakat Terhadapnya di Kabupaten Pekalongan. Makalah dalam Pekan Ilmiah Tahunan Ikatan Geograf Indonesia (PIT IGI) 2014 Universitas Negeri Yogyakarta

Nick Brooks, W. Neil Adgerb, and P. Mick Kelly. 2005.The Determinants of Vulnerability and Adaptive Capacity at The National Level and the Implications for Adaptation. Global Environmental Change 15 (2005), pp 151-163

Oktorie, O. 2017. A Study of Landslide Areas Mitigation and Adaptation in Palupuah Subdistrict, Agam Regency, West Sumatra Province, Indonesia. Sumatra Journal of Disaster, Geography and Geography Education. Volume 1. Issue. 1. p: 43-49. Master Program of Geography Education

Putra A., S. Husrin and Triyatno. 2013. Analisa Bencana Banjir di Kota Padang (Studi Kasus Intensitas Curah Hujan Kota Padang 1980-2009 dan Aspek Geomorfologi). Prosiding Seminar Sains Atmosfer 2013. 24-33.

Putra, A., U.J. Wisha and Kusumah. 2017. Spatial Analysis of River Line and Land Cover Changes in Kampar River Estuary: The Influence of Tidal Bore Bono Phenomenon. Indonesian Journal of Spatial and Regional Analysis (Forum Geografi), 31(2), 220-231.

Qing Tian, Shilun Yang. 2016. Regional Climatic Response to Global Warming: Trends in temperature and precipitation in the Yellow, Yangtze and Pearl River basins since the 1950s. Quaternary International (2016), pp 1-11

Sampei, Y., R.Watanab and Y. Shimatani. 2016. Smart Adaptation Activities And measures Against Urban Flood Disasters, journal Sustainable Cities and Society. 
Su Rito Hardoyo, Muh Aris Marfai, Novi Maulida Ni’mah, Rizki Yustiana Mukti, Qori'atu Zahro, Anisa Halim. 2011. Strategi Adaptasi Masyarakat Dalam Menghadapi Bencana Banjir pasang Air Laut di Kota Pekalongan. Magister Perencanaan dan Pengelolaan Pesisir dan Daerah Aliran Sungai (MPPDAS) Program S-2 Geografi , Fakultas Geografi Universitas Gadjah Mada

Tom R. Burns, and Nora Machado Des Johansson, 2017. Disaster Risk Reduction and Climate Change Adaptation-A Sustainable Development Systems Perspective. Sustainability 2017, 9, 293, pp 1-14 